
Hukum Ius Quia Iustum faculty of Law, Universitas Islam Indonesia. ISSN 0854-8498 I e-ISSN: 2527-502.

Open access at: http://jurnal.uii.ac.id/index.php/IUSTUM

JH Ius Quia Iustum is licensed under a Creative Commons Attribution 4.0 Intemational License. which permits unrestricted use, distribution, and reproduction in any medium, provided the original work is properly cited

\title{
Model Kebijakan Hukum Tanggung Jawab Sosial Perusahaan di Indonesia
}

\author{
Sefriani dan Sri Wartini \\ Fakultas Hukum Universitas Islam Indonesia \\ Jln. Tamansiswa 158 Yogyakarta \\ sefriani@uii.ac.id; sri wartini@uii.ac.id
}

Naskah diterima: 19/7/2016; revisi: 23/11/2016; disetujui: 15/12/2016

\begin{abstract}
This research is to study the model of legal policy of CSR in Indonesia to be effectively and beneficially implemented for the companies, community and environments. This is a normative research using the statue approach, historical approach and comparative approach. The data obtained from the research were grouped in accordance with each variable to later on be analyzed qualitatively and presented in the analytical descriptive form. The result of the research showed that the model of legal policy of CSR in Indonesia is mandatory supported by the proper sanction. Any change of paradigm of Human Right also seeing the company as the one responsible for the ecosob is a strong supporting factor for the legal policy of CSR in Indonesia.
\end{abstract}

Keyword: Model of legal policy; corporate social responsibility

\section{Abstrak}

Penelitian ini mengkaji model kebijakan hukum CSR di Indonesia agar dapat dilaksanakan secara efektif dan bermanfaat bagi perusahaan, negara, masyarakat, serta lingkungan. Penelitian ini merupakan penelitian normatif dengan menggunakan pendekatan perundang-undangan (statute approach), pendekatan historis (historical approach), pendekatan konsep (conceptual approach), serta pendekatan perbandingan (comparative approach).Data yang diperoleh dari penelitian dikelompokkan sesuai dengan variabel masing-masing untuk selanjutnya dianalisis secara kualitatif, dan dipaparkan dalam bentuk deskriptif analitis. Hasil penelitian menunjukkan bahwa model kebijakan hukum CSR Indonesia yang bersifat mandatory disertai sanksi sudah tepat. Perubahan Paradigma Hukum HAM yang juga menjadikan perusahaan sebagai pengemban kewajiban hak ekosob merupakan faktor pendukung yang kuat terhadap model kebijakan hukum CSR Indonesia.

Kata-kata Kunci: Model kebijakan hukum; corporate social responsibility 


\section{Pendahuluan}

Berbagai tujuan dan alasan dibentuknya peraturan perundang-undangan disebut sebagai politik hukum atau kebijakan hukum (legal policy). Dalam pembuatan peraturan perundang-undangan, kebijakan atau politik hukum ini sangat penting, setidaknya untuk dua hal. Pertama, sebagai alasan mengapa diperlukan pembentukan suatu peraturan perundang-undangan. Kedua, untuk menentukan apa yang hendak diterjemahkan ke dalam kalimat hukum dan menjadi perumusan pasal. Keduanya sangat penting karena keberadaan peraturan perundang-undangan dan perumusan pasal merupakan 'jembatan' antara politik hukum yang ditetapkan dengan pelaksanaan dari politik hukum tersebut dalam tahap implementasi peraturan perundang-undangan. Hal ini mengingat antara pelaksanaan peraturan perundang-undangan harus konsisten dan memiliki korelasi yang erat dengan apa yang ditetapkan sebagai politik hukum. ${ }^{1}$

Kebijakan atau Politik hukum dapat dibedakaan dalam dua dimensi. Dimensi pertama adalah politik hukum yang menjadi alasan dasar dari diadakannya suatu peraturan perundang-undangan, yang disebut juga sebagai "Kebijakan Dasar" (basic policy). Dimensi kedua adalah Kebijakan Pemberlakuan" (enactment policy) yaitu tujuan atau alasan yang muncul dibalik pemberlakukan suatu peraturan perundang-undangan. Dimensi ini sangat dominan di negara berkembang mengingat peraturan perundang-undangan seringkali dijadikan instrumen politik oleh pemerintah, baik untuk hal yang bersifat positif maupun negatif. ${ }^{2}$

Beberapa contoh kebijakan dasar terkait hukum bidang ekonomi misalnya kebijakan dasar UU Hak Cipta untuk memberikan perlindungan bagi pencipta atas ciptaannya. Kebijakan Dasar UU Kepailitan untuk membebaskan debitur yang sudah tidak mampu lagi membayarutangnya dan memfasilitasi kreditur untuk mengambil kembali haknya dari debitur. ${ }^{3}$

Adapun Kebijakan pemberlakuan Undang-Undang Hak Cipta tidak sekedar untuk melindungi pencipta atas hasil ciptaannya, tetapi juga untuk memberi iklim investasi yang kondusif bagi investor asing. Amandemen terhadap UU Kepailitan

${ }^{1}$ Hikmahanto Juwana, "Politik Hukum UU Bidang Ekonomi di Indonesia”, Jurnal Hukum, Vol. 01, No.1, 2005, hlm.24

IIbid., hlm. 24

IIbid, hlm. 24-25 
dilakukan tidak sekedar untuk memenuhi kebijakan dasar tetapi juga untuk memenuhi persyaratan yang diminta oleh lembaga keuangan internasional. UU Persaingan Usaha dibentuk di samping memenuhi kebijakan dasarnya juga dimaksudkan untuk membuka pasar yang tertutup dari suatu negara karena pasar tersebut didominasi oleh pelaku usaha yang dekat dengan elit politik. ${ }^{4}$

Kebijakan pemberlakuan sarat muatan politis mengingat pada dasarnya kebijakan pemberlakuan ini tergantung pada apa yang diinginkan pembuat UU. Hal ini berbeda dengan kebijakan dasar yang relatif lebih netral karena bergantung pada nilai universal dari tujuan pembentukan suatu peraturan perundangundangan. ${ }^{5}$ Kebijakan pemberlakuan mengakibatkan substansi undang-undang dengan nama sama, muatannya bisa berbeda-beda antara negara satu dengan yang lain meskipun kebijakan dasarnya sama. Kebijakan pemberlakuan umumnya dipengaruhi faktor-faktor yang datangnya dari dalam negeri (internal) dan faktorfaktor yang datangnya dari luar negeri (eksternal) ${ }^{6}$ Faktor internal umumnya dijadikan dasar filosofis atau sosiologis dibentuknya suatu peraturan perundangundangan yang umumya dirumuskan secara eksplisit di bagian konsiderans ataupun penjelasan umum. Dari penelitian yang dilakukan Hikmahanto Juwana terhadap 14 peraturan bidang ekonomi ditemukan 9 macam kebijakan pemberlakuan masuk dalam kategori faktor internal yaitu mencapai tujuan pembangunan nasional; menggantikan ketentuan yang telah usang; merespons kebutuhan masyarakat; memenuhi keinginan memiliki hukum modern; menciptakan iklim investasi yang kondusif; menjawab tantangan era globalisasi; pemenuhan persyaratan utang dan hibah luar negeri; pemenuhan kewajiban perjanjian internasional; dan memberi dukungan pada kekuasaan. Adapun yang termasuk faktor eksternal adalah melindungi investor; membuka akses pasar Indonesia lebih luas; melakukan harmonisasi hukum Indonesia; memastikan pembayaran utang dan merespons kebutuhan masyarakat. ${ }^{7}$

${ }^{4}$ Ibid., hlm. 26

${ }^{5}$ Loc. Cit.

${ }^{6}$ Loc. Cit.

${ }^{7}$ Ibid., hlm. 26-36 
Keberhasilan dalam menerjemahkan politik hukum akan sangat berpengaruh terhadap implementasi dari UU dan pasal-pasalnya. Dari hasil penelitian terhadap peraturan perundang-undangan bidang ekonomi ditemukan bahwa lemahnya hukum di Indonesia tidak hanya disebabkan permasalahan pada tahap implementasi tetapi juga pada tahapan pembentukan UU (law making process). ${ }^{8}$

Terkait Tanggung jawab Sosial perusahaan (Corporate Social Responsibility (CSR)), yang juga masuk kategori hukum bidang ekonomi, Sejak 2007 Model Kebijakan hukumnya adalah CSR sebagai kewajiban disertai sanksi (mandatory) khususnya bagi perusahaan yang bergerak di sektor usaha sumber daya alam. Hal ini nampak sejak diberlakukannya UU Nomor 25 Tahun 2007 tentang Penanaman Modal dan UU Nomor 40 Tahun 2007 tentang Perseroan Terbatas (PT). ${ }^{9}$

Banyak kritik, pertanyaan sampai gugatan ke Mahkamah Konstitusi diajukan tehadap model kebijakan hukum CSR yang bersifat wajib disertai sanksi ini, mengingat pada umumnya CSR bersifat sukarela dan tidak diatur dalam peraturan perundang-undangan negara. Sampai saat ini, 9 tahun sejak dikeluarkannya UU PT dan UU investasi, belum ada pedoman baku tentang mandatory CSR di Indonesia sehingga menimbulkan kevakuman hukum dan kebingungan bagi kalangan stakeholders CSR di Indonesia baik perusahaan, LSM maupun penerima manfaat program CSR. Terkait hal di atas penelitian ini bermaksud untuk menganalisis bagaimana seharusnya model kebijakan hukum CSR yang tepat di Indonesia untuk terciptanya CSR yang efektif dan bermanfaat bagi negara, perusahaan, dan masyarakat.

${ }^{8}$ Ibid., hlm. 36-38

${ }_{9}$ Lihat Pasal 74 UU 40 tahun 2007 tentang PT dan Pasal 15 UU Nomor 25 Tahun 2007 tentang penanaman modal. Pasal 74 UU PT menyebutkan bahwa (1) Perseroan yang menjalankan kegiatan usahanya di bidang dan/atau berkaitan dengan sumber daya alam, wajib melaksanakan Tanggung Jawab Sosial dan Lingkungan, (2) Tanggung Jawab Sosial dan Lingkungan sebagaimana dimaksud ayat (1) merupakan kewajiban Perseroan yang dianggarkan dan diperhitungkan sebagai biaya Perseroan yang pelaksanaannya dilakukan dengan memperhatikan kepatutan dan kewajaran.PT yang tidak melakukan CSR dikenakan sanksi sesuai dengan peraturan dan perundang-undangan

Pasal 15 UU penanaman modal menyebutkan bahwa setiap penanam modal berkewajiban melaksankan tanggung jawab sosial perusahaan. Jika tidak, maka dapat dikenai sanksi mulai dari peringatan tertulis, pembatasan kegiatan usaha, pembekuan kegiatan usaha dan/atau fasilitas penanaman modal, atau pencabutan kegiatan usaha dan /atau fasilitas penanaman modal. Adapun Penjelasan Pasal 15 huruf b UU Penanaman Modal menyebutkan bahwa yang dimaksud dengan "tanggung jawab sosial perusahaan" adalah tanggung jawab yang melekat pada setiap perusahaan penanaman modal untuk tetap menciptakan hubungan yang serasi, seimbang, dan sesuai dengan lingkungan, nilai, norma, dan budaya masyarakat setempat “ 


\section{Rumusan Masalah}

Permasalahan dalam penelitian ini adalah bagaimana model kebijakan hukum CSR yang tepat di Indonesia untuk terciptanya CSR yang efektif dan bermanfaat bagi negara, perusahaan, dan masyarakat.

\section{Tujuan Penelitian}

Penelitian ini bertujuan untuk menganalis secara mendalam mengenai model kebijakan hukum CSR yang tepat di Indonesia untuk terciptanya CSR yang efektif dan bermanfaat bagi negara, perusahaan, dan masyarakat.

\section{Metode Penelitian}

Penelitian ini merupakan penelitian hukum normatif yang menggunakan data sekunder yang terdiri dari bahan hukum primer, sekunder dan tersier. Semua bahan hukum yang diperoleh dalam penelitian akan dikumpulkan, dikelompokkan sesuai variabel masing-masing, untuk selanjutnya dianalisis secara kualitatif. Dengan menggunakan beberapa pendekatan. Beberapa pendekatan yang digunakan dalam penelitian ini adalah pendekatan perundang-undangan (statute approach), pendekatan historis, pendekatan konsep (conceptual approach), serta pendekatan perbandingan (comparative approach). ${ }^{10}$ Hasil dari penelitian ini akan disajikan dalam bentuk deskriptif analitis.

\section{Hasil Penelitian dan Pembahasan}

Seiring dengan belum jelasnya pengaturan impementasi CSR yang bersifat wajib disertai sanksi di Indonesia, beberapa kementrian seperti Kementerian Lingkungan Hidup, Kementerian Sosial, Kementerian Koperasi dan Usaha Kecil Menengah dan Kementerian Energi dan Sumber Daya Mineral telah berupaya aktif menyusun panduan pelaksanaan program CSR yang bersifat nasional dan sektoral sesuai dengan tugas dan tanggung jawab kementeriannya masing-masing sebagai bentuk sumbangsih konstruktif dalam memperjelas pelaksanaan program CSR di Indonesia. Beberapa panduan tersebut yaitu: ${ }^{11}$ 1. Pedoman CSR Bidang

\footnotetext{
${ }^{10}$ Peter Mahmud Marzuki, Penelitian Hukum, Kencana Prenada Media Group, Jakarta, 2005, hlm. 93-95

${ }^{11}$ Sabela dan Asmah Laili Hj. Yeon, 2015, "Standarisasi CSR Sebagai Kewajiban Hukum di Indonesia", JURNAL ILMU HUKUM, VOLUME 5 NO. 1 Agustus 2014-Januari 2015, hlm. 7, diakses terakhir 31 Mei 2015
} 
Lingkungan yang disusun oleh Kementerian Lingkungan Hidup Republik Indonesia; 2. Petunjuk Pelaksanaan CSR Bidang Lingkungan Hidup yang disusun oleh Kementerian Lingkungan Hidup; 3. Program Penilaian Peringkat Kinerja Perusahaan Dalam Pengelolaan Lingkungan Hidup yang dilaksanakan oleh Kementerian Lingkungan Hidup.

Namun demikian, kurangnya sinergi, sinkronisasi dan harmonisasi diantara kementerian membuat seolah-olah kebijakan CSR berjalan sendir-sendiri. Sinkronisasi dan harmonisasi tidak hanya terhadap kebijakan CSR saja namun juga diperlukan sinkronisasi dan harmonisasi antara program kerja pemerintah baik pusat maupun daerah dan juga aspirasi masyarakat penerima manfaat. Harmonisasi program kerja antara program CSR yang ingin dijalankan dengan program kerja pemerintah baik pusat maupun daerah dan keinginan masyarakat merupakan langkah awal dalam terwujudnya kesuksesan pelaksanaan program:12 Sampai saat ini perusahaan-perusahaan di Indonesia masih menggunakan instrumen internasional dalam menjalankan program CSR seperti:13 1) ISO 26000 on Social Responsibility; 2) Ten Principles of United Nations Global Compact; 3) RSPO (Roundtable for Sustainable Palm Oil); 4) OECD Guidelines for Multinational Enterprises; 5) United Nations Guiding Principles on Business and Human Rights; 6) The Equator Principles

ISO 26000 tidak menggunakan istilah CSR tetapi hanya Social Responsibility, dengan pertimbangan pedoman ISO 26000 diperuntukkan bukan hanya bagi korporasi tetapi bagi semua bentuk organisasi, baik swasta maupun publik. ${ }^{14}$ Menurut ISO 26000 tentang Guidance standard on Social Responsibility ada 7 isu pokok yang harus dilaksanakan perusahaan dalam program CSR nya meliputi: ${ }^{15} 1$. Pengembangan Masyarakat; 2. Konsumen; 3. Praktik Kegiatan Institusi yang Sehat: 4. Lingkungan; 5. Ketenagakerjaan; 6. Hak Asasi Manusia; 7. Organizational Governance (governance organisasi).

\footnotetext{
, College of Law, Government and International Studies, Universiti Utara Malaysia, Sintok, Kedah, Malaysia di http://www.lib.uum.edu.my:8080/bitstream/123456789/1281/1/1221.pdf

${ }^{12}$ Ibid., hlm. 12

${ }^{13}$ Ibid., hlm. 4

14 Mas Achmad Daniri, “Standardisasi Tanggung Jawab Sosial Perusahaan”, diakses terakhir 21 Maret 2015 di http://kadin-indonesia.or.id/enm/images/dokumen/KADIN-167-3770-15042009.pdf, hlm. 4. 15Ibid., hlm. 4.
} 
Prinsip-prinsip dasar tanggung jawab sosial yang menjadi dasar bagi pelaksanaan yang menjiwai atau menjadi informasi dalam pembuatan keputusan dan kegiatan tanggung jawab sosial menurut ISO 26000 meliputi: ${ }^{16}$ 1. kepatuhan kepada hukum; 2. menghormati instrumen/badan-badan internasional; 3. menghormati stakeholders dan kepentingannya; 4. akuntabilitas; 5. transparansi; 6. perilaku yang beretika; 7. melakukan tindakan pencegahan; 8 . menghormati dasardasar hak asasi manusia.

Untuk mendapatkan model kebijakan hukum CSR yang tepat bagi Indonesia perlulah kiranya dilakukan studi perbandingan dengan praktik di negara-negara lain. Dari praktik-praktik tersebut, hal-hal positif bisa dijadikan model untuk diterapkan di Indonesia. Dengan demikian sub bab ini akan dibagi dua meliputi model kebijakan hukum CSR di manca negara, dan model kebijakan hukum CSR di Indonesia.

\section{Model Kebijakan Hukum CSR di Berbagai Negara}

\section{Model Kebijakan Hukum CSR di Inggris}

Pengaturan mengenai pelaksanaan CSR di Inggris dapat dijumpai dalam Companies Act 2006, dimana pemerintah Inggris mewajibkan perusahaan publik untuk melaporkan kinerja sosial dan lingkungan, disamping kinerja usahanya. Laporan ini bersifat terbuka sehingga publik dapat mengakses dan mempertanyakannya sekaligus bisa melakukan pengamatan langsung terhadap realisasi kegiatan CSR yang dilakukan suatu perusahaan Pemerintah Inggris juga telah memiliki divisi khusus yang membidangi Corporate Social Responsibility di bawah Departemen Perdagangan dan Perindustrian.

Terkait CSR ini, pemerintah inggris memiliki strategi sebagai berikut: ${ }^{17}$

1. Promote business activities that bring simultaneous economic, social and environmental benefits.

2. Work in partnership with the private sector, community bodies, unions, consumers and other stakeholders.

3. Encourage innovative approaches and continuing development andapplication of best practice

4. Ensure we have decent minimum levels of performance in areas suchas healty and safety, the environment and equal opportunities.

${ }^{16}$ Ibid., hlm. 6.

${ }^{17}$ Gunawan Widjaja\& Yeremia, A. P.,Risiko Hukum dan Bisnis Perusahaan Tanpa CSR, Forum Sahabat, Jakarta, 2008, hlm. 55. 
5. Encourage increased awareness, open constructive dialogue and trust.

6. Create a policy framework which encourages and enables responsiblebehaviour by business.

Model kebijakan CSR di Inggris melalui pendekatan transparansi laporan. Di Inggris, sudah lama perusahaan diikat dengan kode etik usaha. Satu catatan menarik praktik model kebijakan hukum CSR di Inggris adalah meskipun Inggris memiliki banyak aturan dan undang-undang yang mengatur praktik bisnis di Inggris namun tidak ada UU khusus tentang CSR. Perusahaan di Inggris ini tidak lepas dari pengamatan publik (masyarakat dan negara) karena harus transparan dalam praktik bisnisnya. Publik bisa protes terbuka ke perusahaan jika perusahaan merugikan masyarakat/konsumen/buruh/lingkungan. Melalui Companies Act 2006-nya, Inggris mewajibkan perusahaan yang sudah tercatat di bursa efek untuk melaporkan kinerja ekonomi, finansial juga kinerja sosial dan lingkungan. Laporan ini harus terbuka untuk diakses publik dan dikonfirmasi. Dengan demikian, perusahaan didesak agar semakin meningkatkan transparansi dan bertanggung jawab ${ }^{18}$ Dengan upaya pemerintah yang mendorong transparansi kinerja ini, maka mau tidak mau perusahaan kemudian harus meningkatkan kinerjanya karena iklim persaingan usaha yang ketat akan memberikan disinsentif bagi mereka yang memiliki kelemahan dalam kinerja CSR. Regulasi yang dibuat juga memberikan kewenangan penuh bagi Pemerintah untuk mengecek kebenaran laporan, dan tentu saja mengatur apa konsekuensi kebohongan terhadap publik yang dilakukan perusahaan dalam laporannya. ${ }^{19}$

Setidaknya ada tiga kementrian negara di Inggris yang bertanggung jawab bisnis, lingkungan dan inovasi yaitu: the Department for Business, Innovation and Skills, the Department for Environment, Food and Rural Affairs, the Department for Communities and Local government-community cohesion.

\section{Model Kebijakan Hukum CSR di Perancis}

Di negara Perancis, sistem yang digunakan adalah terpusat pada pemerintah, dimana pemerintah mengambil pajak yang cukup besar terhadap perusahaan-

\footnotetext{
${ }^{18}$ Mas Achmad Daniri, Op. Cit., hlm. 9.

${ }^{19}$ Ibid., hlm. 26.
} 
perusahaan yang berada di negaranya, dan $45 \%$ dari dana tersebut difokuskan bagi pengeluaran-pengeluaran sosial seperti untuk kesehatan, perlindungan sosial, dan dana pensiun. Beberapa perusahaan besar yang menganggarkan biaya pajak dengan beban yang cukup tinggi contohnya seperti Generale des Eaux, Elf Aquitaine dan Rhone Poulenc. Melalui tingginya pembayaran pajak tersebut yang sebagian besar dianggarkan untuk pengeluaran sosial menyebabkan banyak perusahaan beranggapan bahwa mereka secara tidak langsung telah melakukan CSR.

Sistem transparansi laporan juga diterapkan di Perancis. Pemerintah Perancis mengharuskan perusahaan untuk melaporkan secara mendetail dampak kehadiran bisnis mereka dalam aspek sosial dan lingkungan. Perusahaan yang terdaftar di bursa disyaratkan untuk membuat laporan tahunan CSR-nya.

Setidaknya ada dua kementerian di perancis yang memiliki tanggung jawab langsung dalam bidang CSR yaitu Ministry of Solidarity and Social Cohesion, serta the Ministry of Ecology, Sustainable Development, Transports and Housing.20 Hal ini menunjukkan keseriusan Perancis dalam menangani CSR.

\section{Model Kebijakan Hukum CSR di Kanada}

Pemerintah Kanada memiliki kebijakan yang tegas terkait lingkungan, ekonomi dan sosial masyarakatnya. Departemen yang menaungi penyusunan regulasi CSR di Negara ini adalah departemen perindustrian. Secara detail pelaksanaan CSR dilakukan melalui beragam praktik bisnis, seperti: ${ }^{21}$ a. Menjunjung etika dan tata kelola perusahaan yang baik; b. Pengelolaan lingkungan yang sehat dan aman; c. Masalah hak asasi manusia; d. Pengembangan dan pemberdayaan masyarakat; e. Perlindungan konsumen; f. Antikorupsi, serta; g. Laporan yang transparan dan bertanggung jawab.

Sama halnya dengan Inggris, Pemerintah Kanada tidak membuat undangundang yang khusus mengatur pelaksanaan CSR, namun bukan berarti pemerintah Kanada begitu saja membiarkan perusahaan melalaikan kewajiban sosial dan lingkungannya. Kanada bahkan secara tegas mengatur aktivitas CSR

\footnotetext{
${ }^{20}$ Mihaela Irina Ionecsu, 2012, "Corporate Social responsibility: Optional or regulatory", dalam Challenges of the Knowledge Society. Legal sciences diakses 14 agustus 2016 di http://cks.univnt.ro/uploads/cks_2012_ articles/index.php?dir=01_legal_sciences $\% 2$ F\&download=cks_2012_legal_sciences_art_060.pdf, hlm.571

${ }^{21}$ Gunawan Widjaja, Op. Cit., hlm. 57
} 
terkait lingkungan bersifat wajib. Pedoman yang digunakan dalam tata cara pelaksanaan kegiatan CSR disusun secara terperinci melalui panduan umum yang memuat mulai dari konsep apa itu CSR, bagaimana mengembangkan dan mengimplementasikannya, menyusun strategi dan membangun komitmen perusahaan terhadap CSR, hingga tahap evaluasi dan peyusunan laporan kinerja CSR yang dilakukan oleh perusahaan tersebut. Disamping itu, pemerintah Kanada juga menggalakkan pelaksanaan kegiatan CSR dengan cara mensosialisasikan keuntunganyang diperoleh perusahaan dari kegiatan CSR tersebut

\section{Model Kebijakan Hukum CSR di Belgia}

Model kebijakan CSR yang dilakukan oleh Belgia adalah dengan cara menyediakan label khusus bagi perusahaan yang dalam praktiknya sepanjang rantai produksi telah benar-benar sesuai dengan delapan konvensi ILO.

Di negara ini ada beberapa kementrian yang bertanggung jawba terhadap CSR yaitu : Federal Public Service for Employment, Labour and Social Dialogue, the Federal Public Service Economy, SMEs, Middle Classes and Energy, the Federal Public Service for Programming covering the following areas: Social integration and Social Economy and Poverty reduction, Sustainable development, Science policy and, finally, Protection of consumers. ${ }^{22}$

\section{Model Kebijakan Hukum CSR di Amerika Serikat}

Di Amerika, CSR dilakukan perusahaan dalam berbagai bentuk aktifitas seperti memperbaiki tempat hidup pekerja di luar lingkungan kerja seperti perumahan, transportasi, kesehatan, sekolah dan rekreasi. ${ }^{23}$ Perusahaan Amerika yang beroperasi di luar negeri diharuskan melaksanakan Sullivan Principal dalam rangka melaksanakan Corporate Social Responsibilty, yaitu: 1. tidak ada pemisahan ras (non separation of races) dalam makan, bantuan hidup dan fasilitas kerja; 2 . sama dan adil dalam melaksanakan pekerjaan (equal and fair employment process); 3. pembayaran upah yang sama untuk pekerjaan yang sebanding (equal payment

${ }^{22}$ Mihaela Irina Ionecsu, 2012, Corporate Social responsibility: Optional or regulatory, dalam Challenges of the Knowledge Society. Legal sciences diakses 14 agustus $2016 \mathrm{di}$ http://cks.univnt.ro/uploads/cks 2012

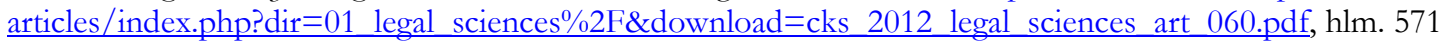

${ }^{23}$ M. Yahya Harahap, "Sinopsis UU No. 40 Tahun 2007 tentang Perseroan Terbatas", Makalab Seminar disampaikan di Gedung Manggala Wanabakti, Jakarta, 20 November 2007. 
compansable work); 4. program training untuk mempersiapkan kulit hitam dan non kulit putih lain sebagai supervisi, administrasi, klerk, teknisi dalam jumlah yang substansial; 5. memperbanyak kulit hitam dan non kulit putih lain dalam profesi manajemen dan supervisi.

Negara-negara di Amerika Serikat dan Eropa, juga Kanada dan Australia umumnya telah mengadopsi code of conduct CSR yang meliputi aspek lingkungan hidup, hubungan industrial, gender, korupsi, dan hak asasi manusia (HAM). Berbasis pada aspek itu, negara mengembangkan regulasi guna mengatur CSR. Australia, misalnya, mewajibkan perusahaan membuat laporan tahunan CSR dan mengatur standardisasi lingkungan hidup, hubungan industrial, dan HAM. Sementara itu, Kanada mengatur CSR dalam aspek kesehatan, hubungan industrial, proteksi lingkungan, dan penyelesaian masalah sosial.24

Belajar dari pengalaman negara-negara lain, mayoritas negara mewajibkan pelaporan CSR. Meskipun CSR sendiri masih berdasarkan sukarela bukan mandatory. Sangat jarang yang secara eksplisit menyatakan bahwa CSR adalah suatu kewajiban disertai sanksi seperti Indonesia.

Di Uni Eropa pada 13 Maret 2007, Parlemen Uni Eropa mengeluarkan resolusi berjudul "Corporate Social Responsibility: A new partnership" yang mendesak Komisi Eropa untuk meningkatkan kewajiban yang terkait dengan persoalanakuntabilitas perusahaan seperti tugas direktur (directors' duties), kewajiban langsungluar negeri (foreign direct liabilities) dan pelaporan kinerja sosial dan lingkunganperusahaan (environmental and social reporting). ${ }^{25}$

Praktik di beberapa negara mensyaratkan adanya laporan pelaksanaan CSR dari berbagai perusahaan yang ada di wilayahnya. Fakta bahwa tidak mudah untuk memperoleh kesepakatan atas ukuran yang digunakan untuk mengukur kinerja perusahaan dalam aspek sosial, namun kewjaiban pelaporan tetap dilakukan. Merespon hal ini, Banyak perusahaan sekarang menggunakan audit eksternal guna memastikan kebenaran laporan tahunan perseroan yang mencakup kontribusi perusahaan dalam pembangunan berkelanjutan, biasanya diberi nama

\footnotetext{
${ }^{24}$ Mas Achmad Daniri, Op. Cit., hlm. 10

${ }^{25}$ Ibid., hlm. 9
} 
laporan CSR atau laporan keberlanjutan. Akan tetapi laporan tersebut sangat luas formatnya, gayanya dan metodologi evaluasi yang digunakan (walaupun dalam suatu industri yang sejenis). Banyak kritik mengatakan bahwa laporan ini hanyalah sekedar "pemanis bibir" (suatu basa-basi).

\section{Model Kebijakan Hukum CSR di China}

China, salah satu raksasa ekonomi di Asia telah bergerak menuju pengaturan CSR yang bersifat mandatory. Perubahan ini didasari beberapa alasan: pertama, kurang perdulinya perusahaan saat bencana alam terjadi. Dalam kasus gempa Sichuan, masyarakat mengkritik habis perusahaan-perusahana besar atas kegagalam mereka berkontribusi membantu korban gempa. Kedua, Perusahaan dianggap mampu berkontribusi membantu negara mengurangi angka kemiskinan, mengurangi kesenjangan sosial. Ketiga, banyaknya kasus skandal korupsi yang melibatkan perusahaan mengakibatkan pentingnya pengaturan CSR secara wajib. ${ }^{26}$ Keempat, keinginan China memperbaiki citranya sebagai negara yang perduli HAM. Perubahan sistem ekonomi dari a centrally planned atau state run economy system ke sistem ekonomi pasar menjadikan banyak investor, perusahaan asing masuk ke China. Perubahan ini membuat pertumbuhan ekonomi China meningkat cukup signifikan. Di sisi lain, China masalah kemiskinan, kesenjangan penghasilan, urbanisasi, perubahan demografi dan maslah kerusakan lingkungan masih menjadi problem yang besar bagi China. Dengan membuat kebijakan CSR sebagai mandatory, China berharap akan ada perbaikan terhadap masalah-masalah yang selama ini dihadapinya. ${ }^{27}$

China sudah memasukkan CSR ke dalam China's Company Law sejak 1994 yang mengadopsi apa yang diberlakukan di Jerman. Perubahan signifikan ada di Company Law 2006 dimana pada Undang-undang yang baru lebih menekankan bahwa bisnis yang beroperasi di China tidak boleh hanya menempatkan profit semata sebagai tujuan perusahaan melainkan juga memprioritaskan moral dan kesejahteraan sosial yang lebih luas.

${ }^{26}$ Afra Afsharipour \& Shruti Rana, "The Emergence of New Corporate Social Responsibility Regimes in China and India, UC Davis Business Law Journal, Vol 14, this article is from Symposium on "Challenges in Achieving Corporate Social Responsibility" on November 21, 2013, hlm. 195.

${ }^{27}$ Ibid., hlm 196 
Ps 5 Company Law 2006 menyatakan sebagai berikut:

In the course of doing business, a company must comply withlaws and administrative regulations, conform to social morality and business ethics, act in good faith, subject itself to the government and the public supervision, and undertake social responsibility

Company Law 2006 mengadopsi ketentuan-ketentuan internasional yang antara lain dapat ditemukan di the OECD on sustainability and CSR, and has endorsed the UN Global Compact, the UN Principles for Responsible Investment, the International Finance Corporation's Equator Principles, and helped develop the ISO2600:2010 standards.

Melengkapi Company Law 2006, untuk lebih memperkuat CSR-nya China juga mengeluarkan Labour Contract Law in 2008, the state-owned Assets Supervision and Administration Commission of the State Council 2008 yang mengatur masalah "Instructions for CSR in State-Owned Enterprises", serta the Chinese Academy of International Trade and Economic Cooperation issued "Guidelines for CSR Compliance for Foreign-Invested Enterprises. ${ }^{28}$

Satu catatan penting terkait pelaksanaan CSR, The Shenzhen Stock Exchange issued "Guide on Listed Companies' Social Responsibility" 2006 serta "Guide on Environmental Information Disclosure for Companies Listed on the Shanghai Stock Exchange 2008. Kedua instrumen ini memperkuat keberadaan the Company Law and the Securities Law. Tujuan utamanya adalah untuk memperkuat CSR dengan publikasi perusahaan yang melaporkan kegiatan CSR dan keterbukaan informasi lingkungan. Tujuan yang lain adalah achieving scientific development, building a harmonious society, advancing toward economic and social sustainable development. Publikasi oleh China's Stock Exchange ini menciptakan efek sanksi reputasi. Dampaknya semakin banyak perusahaan yang melaksanakan CSR dan melaporkannya supaya tidak mendapat reputasi negatif. ${ }^{29}$

Meskipun banyak penulis dari negeri ini menyatakan bahwa china sudah bergerak menuju CSR yang mandatory namun sesungguhnya masih banyak perbaikan yang harus dilakukan untuk lebih memperkuat sifat mandatorynya 
seperti masalah transparansi dan enforcement-nya. Yang ada saat ini hanyalah sanksi reputasi semacam sanksi moral saja. ${ }^{30}$

\section{Model Kebijakan Hukum CSR di India}

Corporate Philantropy sudah lama di praktikkan oleh perusahaan-perusahaan besar di India jauh sebelum istilah CSR dikenal, meskipun tidak di atur dalam undangundang secara khusus. ${ }^{31}$ Perubahan signifikan dilakukan India melalui Company Act 2013. Melalui instrumen hukum ini India menjadikan CSR sebagai bagian daricorporate governance perusahaan ${ }^{32}$ dan bersifat mandatory. Dikatakan membawa perubahan signifikan karena dibandingkan UU sebelumnya 2009 juga 2011 CSR hanyalah sebagai sesuatu yang sifatnya sukarela. Alasan yang digunakan oleh India melakukan perubahan adalah belum terpenuhinya hak ekosob dengan baik di masyarakat. Tingginya angka kemiskinan, pengangguran, kematian bayi dan ibu yang melahirkan, rendahnya tingkat pendidikan, juga tingginya kesenjangan sosial. Perusahaan dianggap dapat berkontribusi membantu pemerintah mengatasi hal ini. April 2013 India memberlakukan Guidelines on Corporate SocialResponsibility and Sustainability for Central Public Sector Enterprises. Melalui aturan ini India menetapkan bahwa setiap Central Public Sector Enterprises (CPSEs) minimal harus memiliki 1 proyek besar untuk pengembangan distrik yang terbelakang. Hal ini dimaksudkan supaya perusahaan berkontribusi terhadap pertumbuhan sosial ekonomi jangka panjang dan berkelanjutan di daerah terbelakang di India

Menurut Company Act 2013 Setiap perusahaan dengan kekayaan bersih rupee lima ratus crore atau lebih (setara USD 81.000.000), atau omzet rupee seribu crore atau lebih (setara dengan USD 162 juta), atau laba bersih rupee lima crore atau lebih (setara dengan USD \$ 811.400) selama tahun anggaran yang berjalan harus membentuk Dewan Komite CSR yang terdiri dari tiga atau lebih direktur dimana satu direktur harus indepen direktur. Tugas komite ini adalah: a. formulating and recommending to the Board, a CSR Policy which must indicate the activities to be

${ }^{30}$ Ibid., hlm. 206.

${ }^{31}$ Ibid.

${ }^{32}$ Caroline Van Zile, Comment, India's Mandatory Corporate Social ResponsibilityProposal: Creative Capitalism Meets Creative Regulation in the Global Market, 13 ASIAN-PAC. L.\& POL'Y J. 269, 271 (2012). 
undertaken by the company; $b$. recommending the amount of CSR expenditure to be incurred on such activities; c. regularly monitoring the CSR initiatives of the company.

Company Act menugaskan komite untuk menjamin dana CSR yang dikeluarkan perusahaan setiap tahun anggaran (financial years). Minimal 2\% dari rata-rata keuntungan bersih perusahaan selama 3 tahun anggaran berturut-turut harus dialokasikan untuk CSR. Apabila perusahaan tidak dapat melaksanakan hal tersebut makan perusahaan harus menjelaskan alasannya ketidakpatuhannya tersebut. Companies Act, Pasal 135(2). ${ }^{33}$

Tujuan pemerintah mewajibkan CSR sebesar 2\% ini adalah untuk membantu pemerintah menghadapi masalah poverty, unemployment, illiteracy and malnutrition serta untuk menjembatani kesenjangan kesejahteraan yang terjadi di masyarakat. ${ }^{34}$

Aktifitas yang dapat dilakukan perusahaan sebagai program CSR mereka adalah sebagai berikut: ${ }^{35} 1$. Eradicating extreme hunger and poverty; 2. Promotion of education; 3. Promoting gender equality and empowering women; 4. Reducing child mortality and improving maternal health; 5. Combating human immunodeficiency virus, acquired immune deficiency; 6. syndrome, malaria and other diseases; 7. Ensuring environmental sustainability; 8. Employment enhancing vocational skills; 9. Social business projects; 10. Contribution to the Prime Minister's National Relief Fund or any otherfund set up by the Central Government or the State Governments forsocioeconomic development and relief and funds for the welfare of theScheduled Castes, the Scheduled Tribes, other backward classes,minorities and women; and 11. Such other matters as may be prescribed

Section 135 juga menyatakan bahwa pelaksanaan CSR diutamakan di wilayah dimana perusahaan beroperasi. ${ }^{36}$ Hal yang perlu digarisbawahi dalam Company Act 2013 ini adalah tidak adanya aturan tentang sanksi bila perusahaan gagal mendistribusikan dananya untuk kegiatan CSR. Sanksi yang ada hanya jika perusahaan tidak melakukan atau melaporkan aktivitas CSR nya serta jika

\footnotetext{
${ }^{33}$ Companies Act, No. 18 of 2013, INDIA CODE (2013), section 1 135(2).

${ }^{34}$ Mandatory Corporate Social Responsibility: Is the Government Shifting its Failure to CorporateIndia? diakses terakhir 4 agustus 2016 dibttps:// socialissuesindia.files.wordpress.com/2012/12/mandatorycsrinindia.pdf, hlm. 3

${ }^{35}$ Companies Act, No. 18 of 2013, INDIA CODE (2013), section 135, Schedule VII.

${ }^{36}$ Selengkapnya Companies Act, No. 18 of 2013, INDIA CODE (2013),section 135 menyatakan sebagai berikut: "stating that a company must "give preference to the local area and areas around it where it operates, for spending the amount earmarked for Corporate Social Responsibility activities"
} 
perusahaan gagal menjelaskan mengapa ia gagal melaksanakan perintah undangundang kewajiban CSR 2\%.

Di dalam menyalurkan dana $2 \%$, perusahaan dapat menggunakan berbagai metode seperrti: ${ }^{37}$ a. Menyalurkannya sendiri; b. Melalui lembaga atau yayasan non profit milik perusahaan sendiri, yang beroperasi di India dan sudah berpengalaman melakukan aktifitas sejenis setidaknya 3 tahun; c. Kolaborasi dengan perusahaan lain

Company Act 2013 ini berlaku efektif mulai agustus 2014. Pelaksanaannya diawasi oleh Corporate Social Responsibility Committee (CSRC), Meskipun menghadapi banyak kritik bahwa undang-undnag ini akan menjadi beban perusahaan, mengalihkan tanggung jawab negara mensejahterahkan warga pada perusahaan, dan lain-lain, namun pemerintah India tetap berkeyakinan untuk menerapkan dan semakin menyempurnakan kebijakan CSR sebagai mandatory ini. Pemerintah berargumen kebijakan ini akan memperluas cakrawala serta memperkuat keberlanjutan perusahaan. Sudah saatnya perusahaan menerima pergeseran paradigma tanggung jawab perusahaan terhadap kesejahteraan masyarakat. Sehingga CSR haruslah diadopsi perusahaan menjadi strategi jangka panjnag dan bukan hanya sebagai suatu kewajiban hukum saja. ${ }^{38}$

Mengapa China dan India mewajibkan CSR ditengah praktik arus kesukarelaan CSR merupkan hal penting untuk diketahui. Dua raksasa ekonomi di Asia ini sangat berpengaruh dikalangan negara berkembang. Peran keduanya juga besar dalam pembentukan Good corporate governance. Dalam pandangan China dan India tata kelola perusahaan dan CSR yang kuat sangat penting untuk baik perusahaan lokal dan investor asing yang tertarik dalam mengejar peluang investasi dari pertumbuhan yang luar biasa di China dan India. Dengan demikian CSR yang kuat tidak hanya akan berdampak pada perusahaan sendiri, populasi, dan lingkungan hukum mereka, tapi juga akan memiliki konsekuensi yang signifikan bagi perusahaan, konsumen dan populasi di seluruh dunia, karena

${ }^{37}$ Afra Afsharipour \& Shruti Rana, Loc.Cit.

${ }^{38}$ Divya mehta \& Monica Aggarwal, "Making Corporate Social Responsibility Mandatory in India-Prospects and Problems", dalam International Journal of Research in Business Management (IMPACT : IJRBM), Vol. 3, Issue 5, May 2015, 21-30, hlm.8, diakses terakhir 14 agustus 2016 di http://www.impactjournals.us/download. php? fname $=2-78-1432556656-4 . \% 20$ Human $\% 20$ Making $\% 20$ CSR $\% 20$ mandatory $\% 20 \mathrm{in} \% 20$ India $\% 20$ Prospects $\% 20$ and $\% 20$ Problems \%20Ms.\%20DIVYA\%20MEHTA.pdf 
kedua negara menjadi bagian yang semakin tidak terpisahkan dari rantai pasokan global dan bahkan mengambil alih kepemilikan saham di pasar ekonomi global. ${ }^{39}$

\section{Model Kebijakan Hukum CSR di Indonesia}

Dari paparan sebelumnya tentang Model Kebijakan Hukum CSR di berbagai negara di dapatkan kesimpulan bahwa di Amerika Serikat dan Eropa, CSR biasanya dipandang sebagai sesuatu program perusahaan atas dasar kesukarelaan, tidak dapat dipaksakan (unforceable), dimana perusahaan akan berusaha beroperasi dengan socially responsible manner. ${ }^{40}$ Model kesukarelaan ini sering disebut sebagai model barat yang merujuk pada tindakan perusahaan yang sukarela dan self regulatory. Di sini CSR bertujuan meyakinkan perusahaan dalam menjalankan bisnisnya disertai aktifitas diluar keterikatan pada hukum dan diluar tujuan memaksimalkan kekayaan pemegang saham. Sampai saat ini pun masih banyak para pakar serta masyarakat yang berpandanagn bahwa mekanisme kerja CSR adalah berdasarkan kesukarelaan. Yang banyak dikembangkan oleh negara-negara maju adalah sistem insentif yang mendorong perusahaan melakukan investasi sosial sebagai bagian dari strategi welfare mix (kesejahteraan sebagai tanggung jawab bersama). Di Amerika Serikat misalnya, dengan pertimbangan penguatan kelompok-kelompok masyarakat sipil, maka perusahaan yangmenyumbang kepada kelompok yang masuk dalam kategori tertentu akan mendapatkan pemotongan pajak. ${ }^{41} \mathrm{Kalaupun}$ ada unsur mandatory di beberapa negara di kawasan Amerika dan Eropa, ini adalah sebatas pada kewjaiban melaporkan aktifitas CSRnya pada lembaga yang berwenang. Semakin berkembangnya konsep CSR dan metode verifikasi laporannya, kecenderungan yang terjadi sekarang adalah peningkatan kebenaran isi laporan aspek sosial. Sementara aspek lingkungan, apalagi aspek ekonomi, memang jauh lebih mudah diukur. ${ }^{42}$ Gagalnya perusahaan melaporkan aktifitas CSR-nya berpotensi menurunkan reputasi dan kredibilitas perusahaan. Hal yang sama juga diterapkan di China. Satu-satunya

\footnotetext{
${ }^{39}$ Afra Afshariour dan Shruti Rana, Op. Cit., hlm. 183.

${ }^{40}$ Johan Graafland \& Lei Zhang, "Corporate Social Responsibility in China: Implementation and Challenges", Business Ethics: A European Rev. Vol. 21 Issue 1, 2014, hlm. 35.

${ }^{41}$ Mas Achmad Daniri, Op. Cit., hlm. 25-26

${ }^{42}$ Ibid., hlm. 11.
} 
negara yang sudah sangat tegas mengatur CSR sebagai suatu kewajiban beserta besaran yang harus dikeluarkan oleh perusahaan adalah India.

Sekalipun perdebatan apakah CSR merupakan voluntary atau mandatory sudah berlangsung lama,dan masih banyak negara yang menerapkan CSR sebagai sesuatu di luar koridor hukum, sifatnya adalah sukarela, namun dapat dicatat bahwa dari waktu ke waktu semakin banyak ahli yang mendukung diwajibkannya CSR. Michael Kerr, Richard Janda dan Chip Pitt sebagaimana dikutip oleh Afra Afshariour dan Shruti Rana menuliskan bahwa:43 "the law now weighs in to give substance, meaning, and accountability to CSR undertakings

Sebagaimana telah dipaparkan dalam sub bab-sub bab pendahuluan, tanggung jawab sosial dan lingkungan atau CSR di Indonesia di atur oleh UU tentang PT juga UU tentang Penanaman modal, UU tentang BUMN beserta peraturan-peraturan pelaksananya. Dengan demikian model kebijakan hukum TJSL di Indonesia dapat diketahui antara lain dari instrumen-instrumen hukum ini.

Kebijakan dasar pembentukan UU yang memuat CSR di atas antara lain adalah untuk mendukung kelembagaan perekonomian yang kokoh dalam rangka mewujudkan kesejahteraan masyarakat; terselenggaranya iklim duniausaha yang kondusif; untuk memberikan landasan hukum pada PT agar lebih memacu pembangunan nasional; meningkatkan penanaman modaluntuk mengolah potensi ekonomi menjadi kekuatan ekonomi riil; terciptanya iklim penanaman modal yang kondusif, promotif, memberikan kepastian hukum, keadilan, dan efisien dengan tetap memperhatikan kepentingan ekonomi nasional. Kebijakan dasar ini memang sangat umum, tidak menyentuh CSR secara langsung karena memang UU tersebut tidak khusus mengatur CSR.

Kebijakan dasar yang khusus tentang CSR ditemukan dalam penjelasan PP 47 Tahun 2012 tentang tanggung Jawab Sosial dan Lingkungan Perseroan Terbatas yang menyatakan bahwa tujuan dibuatnya PP adalah mewujudkan pembangunan ekonomi berkelanjutan guna meningkatkan kualitas kehidupan dan lingkungan yang bermanfaat bagi komunitas setempat dan masyarakat pada umumnya maupun Perseroan itu sendiri dalam rangka terjalinnya hubungan Perseroan yang

${ }^{43}$ Afra Afshariour dan Shruti Rana, Op. Cit., hlm. 180. 
serasi, seimbang, dan sesuai dengan lingkungan, nilai, norma, dan budaya masyarakat setempat

Lebih lanjut PP menyatakan pula bahwa pengaturan tanggung jawab sosial dan lingkungan PT dimaksudkan untuk: 1. meningkatkan kesadaran Perseroan terhadap pelaksanaan tanggung jawab sosial dan lingkungan di Indonesia; 2. memenuhi perkembangan kebutuhan hukum dalam masyarakat mengenai tanggung jawab social dan lingkungan; dan 3. menguatkan pengaturan tanggung jawab sosial dan lingkungan yang telah diatur dalam berbagai peraturan perundang-undangan sesuai dengan bidang kegiatan usaha Perseroan yang bersangkutan.

Dalam putusannya Nomor 53/PUU-VI/2008 yang menolak permohonan pembatalan Pasal 74 UU PT dan penjelasannya yang mengatur tentang CSR, Mahkamah Konsitusi, antara lain menyatakan sebagai berikut ;

1. Tanggung Jawab Sosial dan Lingkungan (TJSL) merupakan kebijakan negara yang menjadi tanggung jawab bersama negara, pelaku bisnis, perusahaan, dan masyarakat. Bukan sebaliknya untuk dicari kelemahannya untuk justifikasi menghindari (to evade) tanggung jawab tersebut. TJSL merupakan affirmative regulation yang menurut aliran hukum alam bukan saja menuntut untuk ditaati, tetapi menuntut kerja sama antara pemangku kepentingan;

2. Kerusakan sumber daya alam dan lingkungan di Indonesia telah sampai pada tingkat yang sangat mengkhawatirkan. Negara berhak untuk mengatur, mengusahakan, memelihara dan mengawasi, untuk terwujudnya sustainable development yang ditujukan kepada semua stakeholders yang tidak boleh dikurangi atau bahkan diabaikan;

3. Bahwa negara, masyarakat, dan perusahaan yang bergerak dalam eksploitasi dan pemanfaatan sumber daya alam sudah semestinya ikut bertanggung jawab baik secara moral maupun hukum terhadap dampak negatif atas kerusakan lingkungan tersebut. Membangun dilakukan dengan prinsip pareto superiority, berarti membangun dan mendapat keuntungan tanpa mengorbankan kepentingan orang lain;

4. Penormaan Tanggung Jawab Sosial dan Lingkungan (TJSL) menjadi kewajiban hukum merupakan kebijakan hukum (legal policy) pembentukUndang-Undang untuk mengatur dan menerapkan TJSL dengan suatu sanksi.Hal ini dilatarbelakangi kondisi sosial dan lingkungan yang rusak pada masa lalu dimana praktik perusahaan yang mengabaikan aspek social dan lingkungan, sehingga mengakibatkan kerugian bagi masyarakat sekitarpada khususnya dan lingkungan pada umumnya; 
5. Sebagai negara berdaulat Indonesia tidak harus mengikuti negara lain dalam mengatur CSR. CSR harus disesuaikan dengan budaya negara masing-masing. regulasi mandatory diperlukan untuk menegakkan CSR di Indonesia;

6. Hubungan antara moral dan etik dengan hukum adalah bersifatgradual, dimana hukum merupakan formalisasi atau legalisasi dari nilai-nilai moral. Dalam hubungan ini, nilai-nilai moral dan etik yang diterima secara sukarela (voluntary) dan dianggap penting dapat saja diubah secara gradual menjadi hukum atau undang-undang agar lebih mengikat.

7. Harus dibedakan antara pungutan pajak oleh negara dan danaperusahaan untuk TJSL. Pajak untuk pembangunan nasional, sedangkan dana TJSL digunakan untuk masyarakat dan pemulihan lingkungan sekitar perusahaan. TJSL bukan pungutan ganda karena biaya yang dikeluarkan untuk TJSL akan diperhitungkan sebagai biaya perseroan dan pelaksanaannya didasari oleh kemampuan perusahaan berdasar kepatutan dan kewajaran"yang akan diatur dengan Peraturan Pemerintah.

8. Bahwa pengaturan TJSL dengan kewajiban hukum (legal obligation) lebih mempunyai kepastian hukum jika dibandingkan yang bersifatsukarela.

9. Sanksi TJSL akan diatur dalam undang-undang sektoral bukan di UU PT untuk lebih menjamin kepastian hukum, karena tidak menimbulkan adanya pertentangan diantara Undang-Undang;

10. Penormaan CSR dalam Pasal 74 UU 40/2007 telah mencerminkankeadilan sosial. John Rawls menghubungkan konsep keadilan dengan duanilai fundamental dari tertib sosial, yaitu kebebasan dan persamaan. Setiap orang mempunyai hak yang sama untuk mendapat jaminan kebebasan yang paling mendasar. Dalam suatu masyarakat yang menjalankan persaingan pasar bebas yang apabila terdapat kepentingan yang berbeda disebabkan adanya perbedaan sosial ekonomi, maka kebijakan harus lebih mengutamakan kepentingan mereka yang paling kurang diuntungkan supaya kesenjangan sosial tidak semakin lebar dan akan lebih mendekatkan pada keadilan sosial. Tanggung jawab sosial perusahaan dapat dilihat sebagaisarana untuk menciptakan keadilan sekaligus memberikan keadilan pada generasi yang akan datang;

11. TJSL hanya ditujukan untuk perseroan yang menjalankan kegiatan usahanya di bidang atau berkaitan dengan sumber daya alam karena berkaitan dengan Pasal 33 ayat (3) UUD 1945 sehingga negara berhak untuk mengatur secara berbeda. Adapun terhadap badan usaha lain selain perseroan terbatas, seperti Koperasi, CV, Firma, dan Usaha Dagang, dikenai juga kewajiban tanggungjawab sosial perusahaan sebagaimana diatur dalam Pasal 15 UndangUndang Nomor 25 Tahun 2007 tentang Penanaman Modal yang lebih dulu diundangkan dari pada UU 40/2007, yang berbunyi, "Setiap penanam modal berkewajiban.....melaksanakan tanggung jawab sosial perusahaan...;

12. Kekhawatiran para Pemohon pelaksanaan TJSL hanya formalitas dan menimbulkan bentuk korupsi baru, tidaklah benar karena perusahaan sendirilah yang melaksanakan TJSL sesuai dengan prinsip kepatutan dan kewajaran. Peranan Pemerintah hanya sebagai pemantau dan memberikan sanksi sesuai Undang-Undang sektoral bila TJSL tidak dilaksanakan. 
13. Prinsip dasar perekonomian di Indonesia adalah bersifat kerakyatan. Pengaturan CSR dengan suatu kewajiban hukum merupakan suatu cara Pemerintah untuk mendorong perusahaan ikut serta dalam pembangunan ekonomi masyarakat. Penormaan ini telah sejalan dan tidak bertentangan dengan Pasal 33 ayat (4) UUD 1945 khususnya pada frasa efisiensi berkeadilan. ${ }^{4}$

Pada dasarnya pertimbangan-pertimbangan hukum yang dikemukakan oleh Mahkamah Konstitusi di atas dapat membantu menjelaskan tentang kebijakan pemberlakuan pengaturan TJSL perusahaan yang bersifat mandatory. Sudah saatnya Indonesia memiliki kebijakan hukum penormaan TJSL sebagai mandatory dengan sanksi. Meskipun demikian supaya ketentuan tersebut dapat diimpelementasikan dengan baik, memberi kepastian hukum, efektif dan memberi manfaat bagi perusahaan, negara, masyarakat dan lingkungan sekitar untuk tercapainya sustainable development pada pembangunan nasional maka perlu dilakukan perbaikan terhadap ketentuan-ketentuan yang masih menimbulkan ketidakjelasan maupun kevakuman.

Beberapa catatan yang ditemukan dalam model kebijakan hukum TJSL Indonesia saat ini antara lain sebagai berikut: pertama, belum ada istilah yang seragam di Indonesia untuk menyebut tanggung jawab sosial perusahaan (CSR). Pasal 15 UU tentang penanaman modal menggunakan istilah tanggung jawab sosial perusahaan (CSR). Pasal 74 UU tentang PT menggunakan istilah Tanggung jawab social lingkungan (TJSL) perusahaan, terkandung makna aspek lingkungan lebih mendapat perhatian dibanding aspek sosial yang lain. Pasal 2 dan Pasal 88 Undang-Undang No. 19 Tahun 2003 tentang Badan Usaha Milik Negara (UU BUMN), menggunakan istilah Program Kemitraan dan Bina Lingkungan (PKBL). 45 Hal ini dapat menimbulkan kebingungan dalam praktik.

${ }^{44}$ Putusan MK Nomor 53/PUU-VI/2008 hlm. 89-98.

${ }^{45}$ Pasal 11 ayat (2) huruf e Permeneg BUMN No.Per-05/MBU/2007 merumuskan ruang lingkup bantuanprogram Bina Lingkungan adalah sebagai berikut: 1. bantuan korban bencana alam; 2. bantuan pendidikan dan/atau pelatihan; 3. bantuan peningkatan kesehatan; 4. bantuan pengembangan prasarana dan/atau sarana umum; 5 . bantuan sarana ibadah; 6, bantuan pelestarian alam.

Di dalam praktik, yang masuk kategori kegiatan bina lingkungan antara lain: bantuan bencana alam, bantuan kesehatan, khitanan masal, penerangan jalan sekitar perusahaan, bantuan sarana umum dan tempat ibadah, beasiswa pendidikan masyarakat sekitar, bantuan hari raya, bantuan olah raga masyarakat sekitar, seni dan budaya, donor darah, operasi katarak, bibir sumbing, serta bentuk kegiatan sejenisnya. Bantuan bina lingkungan ini ditujukan untuk membantu masyarakat sekitar yang tidak memiliki kontraprestasi langsung secara ekonomi. Sementara bantuan kemitraan yang dimaksud di dalam UU BUMN secara implementasi diwujudkan sebagai 
Kedua, CSR tidak membatasi bentuk perusahaan tetapi model kebijakan hukum CSR Indonesia membatasi pada perusahaan penanaman modal, dan Perseroan yang bergerak atau berkaitan usahanya dengan sumber daya alam (SDA) saja. ${ }^{46}$ Hal ini terkesan tidak adil mengingat jika dicermati sesungguhnya bukan hanya perusahaan-perusahaan tersebut yang mencari keuntungan dan berpotensi mempunyai dampak terhadap masyarakat.

Ketiga, TJSL di Indonesia terkesan sangat sempit seolah sebagai bagian dari community development. Hal ini nampak dari perumusan tujuan TJSLyang sama dengan tujuan community development. Dalam Community Development dirumuskan bahwa Community development merupakan komitmen peran serta perseroan dalam pembangunan ekonomi berkelanjutan, merupakan alat yang digunakan untuk meningkatkan kualitas kehidupan dan lingkungan yang bermanfaat, baik bagi Perseroan sendiri, komunitas setempat maupun masyarakat pada umumnya. Sedangkan tujuan (TJSL) adalah untuk tetap menciptakan hubungan perseroan yang serasi, seimbang dan sesuai dengan lingkungan, nilai, norma dan budaya masyarakat setempat. Dapat dilihat di sini bahwa tujuan TJSL yang dirumuskan dalam UUPT terkesan seperti tujuannya $C D$, padahal $C D$ lebih sempit dari CSR, karena CD merupakan bagian kecil dari CSR. ${ }^{47}$

Keempat, belum jelasnya pengaturan mengenai perhitungan anggaran sebagai biaya perseroan yang memperhatikan aspek kepatutan dankewajaran. Demikian pula mengenai sanksi, belum dijelaskan secara rinci, melainkan diserahkan pada ketentuan perundang-undangan. Faktanya, ketentuan perundang-undangan yang mengatur mengenai hal tersebut belum ada sampai saat ini. Lebih lanjut, tidak ada award bagi perusahaan yang menjalankan Corporate Social Responsibility dengan baik.

Kelima, belum diaturnya bentuk-bentuk kegiatan CSR yang wajib dilakukan oleh Perseroan Terbatas yang menyebabkan tidak adanya indikator yang jelas

\footnotetext{
bantuan dana bergulir dan kemitraan dalam rangka pengembangan usaha. Bentuk kemitraan yang dilakukan perusahaan yakni seperti: bantuan kredit lunak (dana bergulir) untuk koperasi dan UKMK, bantuan pemasaran, bantuan manajemen, pelatihan perbengkelan, bantuan teknis, bantuan jaringan pengembangan usaha dan sejenisnya.

${ }^{46}$ Djuhaendah Hasan dkk, Pengkajian Hukum Tentang Tanggung Jawab Sosial perusahaan, BPHN, Depkumham, Jakarta, 2009, hlm. 13

${ }^{47} I b i d .$, hlm. 14
} 
mengenai sudah terpenuhinya atau belum kewajiban melakukan kegiatankegiatan CSR tersebut oleh Perseroan Terbatas. Tidak heran oleh karenanya banyak perusahaan melaksanakan CSR secara tidak tepat. ${ }^{48}$

Terlepas dari masih cukup banyaknya kekurangan model kebijakan hukum CSR Indonesia saat ini, beberapa hal yang dapat direkomendasikan adalah sebagai berikut: pertama, Model kebijakan hukum CSR Indonesia sudah pada jalur yang benar, mengatur CSR dalam suatu instrumen hukum dan mengubah sifat CSR dari voluntary menjadi mandatory. Indonesia memiliki kedaulatan untuk membuat model hukum kebijakan CSR sebagai suatu kewajiban disertai sanksi, meskipun mayoritas negara masih mengaturnya dalam bentuk voluntary. Hal ini penting karena manakala CSR di Indonesia masih bersifat voluntary maka tidak akan efektif. CSR menuntut biaya sehingga akan menaikkan harga produk barang dan jasa. Konsumen tidak akan mau membayar lebih mahal jika ada pilihan yang lebih murah. Akibatnya jika CSR hanya sukarela akan banyak perusahaan yang tidak melaksanakan CSRnya untuk menekan biaya produksi. Untuk CSR harus dikawal melalui peraturan perundang-undangan dan melibatkan kontrol pemerintah. ${ }^{49}$

Kedua, Belajar dari model kebijakan CSR di berbagai negara nampak bahwa Pendekatan yang digunakan oleh masing-masing negara terkait dengan kebijakan hukum CSR nya adalah berbeda-beda. Namun demikian, pelaksanaan CSR seyogyanya disesuaikan dengan kemampuan masing-masing perusahaan dan kebutuhan masyarakat lokal. Idealnya terlebih dahulu dirumuskan bersama antara 3 pihak yang berkepentingan yakni pemerintah, dunia usaha dan masyarakat setempat dan kemudian dilaksanakan sendiri oleh masing-masing perusahaan, karena masing-masing perusahaan memiliki karakteristik lingkungan dan masyarakat yang berbeda antara satu dengan yang lain. Upaya perusahaan menerapkan CSR memerlukan sinergi dari pemerintah dan masyarakat. Pemerintah sebagai regulator diharapkan mampu berperan menumbuh kembangkan penerapan CSR di tanah air tanpa membebani perusahaan secara

\footnotetext{
${ }^{48}$ Marianne Magda Ketaren, "Strengthening the Corporate Social Responsibility Regime in Indonesia", International Journal of Humanities and Social Science, Vol. 4, No. 9 (1); July 2014, hlm. 3

${ }^{49}$ David Vogel, The Market for Virtue: The Potential and Limits of Corporate Social Responsibility, The Brookings Institution, Washington, D.C., 2005, hlm. 172
} 
berlebihan. Peran masyarakat juga diperlukan dalam upaya perusahaan memperoleh rasa aman dan kelancaran dalam berusaha. ${ }^{50}$

Ketiga, Beberapa usulan dalam pelaksanaan program CSR sebagai sarana pengembangan masyarakat di Indonesia antara lain adalah: a) community relation: kegiatan-kegiatan yang menyangkut pengembangan kesepahaman melalui komunikasi dan informasi kepada para pihak yang terkait. Dalam kategori ini, program lebih cenderung mengarah pada bentuk-bentuk kedermawanan (charity) perusahaan; b) community services: merupakan pelayanan perusahaan untuk memenuhi kepentingan masyarakat atau kepentingan umum. Inti dari kategori ini adalah memberikan kebutuhan yang ada di masyarakat dan pemecahan masalah dilakukan oleh masyarakat sendiri sedangkan perusahaan hanyalah sebagai fasilitator dari pemecahan masalah tersebut; c) community empowering: adalah program-program yang berkaitan dengan memberikan akses yang lebih luas kepada masyarakat untuk menunjang kemandiriannya, seperti pembentukan usaha industri kecil lainnya yang secara alami anggota masyarakat sudah mempunyai pranata pendukungnya dan perusahaan memberikan akses kepada pranata sosial yang ada tersebut agar dapat berlanjut. Dalam kategori ini, sasaran utama adalah kemandirian komunitas. ${ }^{51}$

Model kebijakan hukum CSR Indonesia yang bersifat mandatory disertai sanksi tidaklah bertentangan dengan hukum interasional. Dewasa ini telah terdapat pergeseran paradigma dalam konteks subjek yang mengemban tugas untuk menegakkan HAM khususnya hak-hak Ekosob yang sangat serta kaitannya dengan CSR. Paradigma lama yang menyatakan bahwa negara adalah satusatunya pengemban bagi implementasi hak-hak ekonomi, sosial dan budaya menjadi tidak relevan. Namun perusahaan dengan konsep tanggung jawab sosial perusahannya, harus juga dipandang sebagai pengemban tugas untuk bertanggung jawab terhadap pemajuan (to promote) hak-hak asasi manusia. ${ }^{52}$ Peran perusahaan dalam memajukan hak-hak ekonomi, sosial dan budaya

${ }^{50}$ Djuhaendah Hasan, dkk, Op. Cit., hlm. 43

${ }^{51}$ Mas Achmad Daniri, Op. Cit., hlm. 17

${ }^{52}$ Ahmad Taufik, Hak Asasi Manusia Dan Tanggung Jawab Sosial Perusahaan, http://bandungfreeschool. wordpress.com/2008/11/29/hak-asasi-manusia-dan-tanggung-jawab-sosial-perusahaan/, diakses tanggal 13 Maret 2016 
sangatlah strategis. Hal ini disebabkan, pemenuhan hak-hak tersebut memerlukan sumber daya keuangan yang sangat besar dan perusahaan sebagai entitas bisnis memiliki kemampuan sumber daya keuangan yang sangat besar pula, khususnya perusahan-perusahaan transnasional. Sebagai sebuah ilustrasi 5 perusahaan transnasional terbesar di dunia melebihi dua kali gabungan pendapatan dari 100 negara-negara miskin. Dengan kemampuan finansial yang demikian besar, suatu perusahaan mampu membantu negara dalam memenuhi hak-hak ekosob. Semisal dengan melakukan berbagai program untuk meningkatkan kualitas pendidikan, kualitas kesehatan, menciptakan lapangan pekerjaan dan lain-lain. ${ }^{53}$

Tidak hanya dalam tataran eksternal, di tataran internal terkait persoalan mengenai hak-hak pekerja juga merupakan salah satu aspek terpenting dalam konsep tanggung jawab perusahaan terhadap hak ekosob. Konsep tanggung jawab perusahaan, tidak hanya mendorong agar perusahaan mampu mengikuti standar regulasi peraturan ketenagakerjaan di suatu negara baik itu menyangkut kesejahteraan tenaga kerja, kesehatan dan keselamatan kerja, kebebasan berorganisasi dan hak-hak normatif lainnya. Lebih dari itu, tanggung jawab sosial perusahaan dalam konteks ini juga menempatkan karyawan sebagai pusat dari seluruh aktifitas perusahaan, dengan berbagai program peningkatan kapasitas karyawan dan mengikutsertakan karyawan dalam pengambilan keputusan dengan memberikan kepemilikan saham dalam perusahaan tersebut. Sehingga hal ini dapat mengurangi, tingkat kerentanan pekerja sebagai objek yang dilanggar hak-hak asasinya. Gagasan untuk memberikan peran bagi perusahaan untuk melakukan juga telah didukung oleh PBB melalui Komisi Hak Asasi Manusianya dengan mengeluarkan norma-norma bagi perusahaan transnasional berkaitan dengan hak asasi manusia, pada 26 Agustus 2003.54

\section{Penutup}

Berdasarkan hasil penelitian dan analisis yang telah dilakukan dapat disimpulkan bahwa model kebijakan hukum CSR Indonesia yang bersifat mandatory disertai sanksi sudah tepat. Perubahan Paradigma Hukum HAM yang 
juga menjadikan perusahaan sebagai pengemban kewajiban hak ekosob merupakan faktor pendukung yang kuat terhadap model kebijakan hukum CSR Indonesia. Indonesia merupakan negara berdaulat yang berwenang menetapkan model kebijakan hukum CSRnya menyesuaikan dengan situasi kondisi dan budaya masyarakat di Indonesia yang belum kondusif untuk diterapkannya penormaan yang sifatnya sukarela. Indonesia juga bukan satu-satunya negara yang menormakan CSR sebagai kewajiban disertai sanksi. Beberapa negara juga mulai menerapkan hal yang serupa dengan model kebijakan hukum Indonesia sebagai acuan. India bahkan menerapkan model kebijakan hukum yang mandatory dengan besaran CSR yang sudah fix sebesar 2\% dari keuntungan perusahaan. Tidak mustahil di masa yang akan datang semakin banyak yang mengikuti model kebijakan hukum CSR yang bersifat mandatory disertai sanksi. Meskipun demikian Indonesia masih perlu menyempurnakan model kebijakan hukum ini untuk lebih memberi kepastian hukum terhadap pelaksanaan CSR.

\section{Daftar Pustaka}

\section{Buku}

Hasan, Djuhaendah dkk, Pengkajian Hukum Tentang Tanggung Jawab Sosial Perusahaan, BPHN, Depkumham, Jakarta, 2009.

Marzuki, Peter Mahmud, Penelitian Hukum, Kencana Prenada Media Group, Jakarta, 2005.

Vogel, David, The Market for Virtue: The Potential and Limits of Corporate Social Responsibility, The Brookings Institution, Washington, D.C, 2005.

Widjaja, Gunawan \& Yeremia, A. P. Risiko Hukum dan Bisnis Perusahaan Tanpa CSR. Jakarta, Forum Sahabat, 2008.

\section{Artikel Jurnal}

Afsharipour, Afra \& Shruti Rana, “The Emergence of New Corporate Social Responsibility Regimes in China and India", UC Davis Business Law Journal, Vol. 14, 2013.

Caroline Van Zile, Comment, India's Mandatory Corporate Social ResponsibilityProposal: Creative Capitalism Meets Creative Regulation in the Global Market, 13 Asian-Pac. L.\& Pol'y J. 269, 2012.

Graafland, Johan \& Lei Zhang, "Corporate Social Responsibility in China: Implementation and Challenges", 23 Bus. Ethics: A European Review, 2014. 
Juwana, Hikmahanto, "Politik Hukum UU Bidang Ekonomi di Indonesia", Jurnal Hukum, Vol. 01, No. 1, 2005.

Ketaren, Marianne Magda, "Strengthening the Corporate Social Responsibility Regime in Indonesia", International Journal of Humanities and Social Science, Vol. 4, No. 9(1); July 2014

Mehta, Divya \& Monica Aggarwal, (May 2015), "Making Corporate Social Responsibility Mandatory in India-Prospects and Problems", dalam International Journal of Research in Business Management ( IMPACT : IJRBM ), Vol. 3, Issue 5, diakses terakhir 14 agustus 2016 di http:/ / www.impactjournals.us/download.php?fname=2-78-1432556656-

4.\%20Human \%20Making\%20CSR\%20mandatory $\% 20$ in $\% 20$ India $\% 20$ Prospects\%20and\%20Problems\%20Ms.\%20DIVYA\%20MEHTA.pdf

Sabela dan Asmah Laili Hj. Yeon, 2015, "Standarisasi CSR Sebagai Kewajiban Hukum di Indonesia", Jurnal Ilmu Hukum, VOLUME 5 NO. 1 Agustus 2014Januari 2015, diakses terakhir 31 mei 2015 , College of Law, Government and International Studies, Universiti Utara Malaysia, Sintok, Kedah, Malaysia di http://www.lib.uum.edu.my:8080/bitstream/123456789/1281/1/1221.pdf.

\section{Makalah}

Harahap, M. Yahya, "Sinopsis UU No.40 Tahun 2007 tentang Perseroan Terbatas", Makalah Seminar disampaikan di Gedung Manggala Wanabakti, Jakarta, 20 November 2007.

Ionecsu, Mihaela Irina, 2012, Corporate Social responsibility: Optional or regulatory, dalam Challenges of the Knowledge Society. Legal sciences, di http://cks.univnt.ro/uploads/cks_2012_articles/index.php?dir=01_legal_ sciences\%2F\&download=cks_2012_legal_sciences_art_060.pdf,_diakses 14 agustus 2016.

\section{Peraturan Perundang-Undangan}

Undang-Undang Nomor 40 Tahun 2007 tentang Perseroan Terbatas (Lembaran Negara Republik Indonesia Tahun 2007 Nomor 106, Tambahan Lembaran Negara Republik Indonesia Nomor 4756).

Undang-Undang Nomor 25 Tahun 2007 tentang Penanaman Modal (Lembaran Negara Republik Indonesia Tahun 2007 Nomor 67, Tambahan Lembaran Negara Republik Indonesia Nomor 4724).

Companies Act, No. 18 of 2013, INDIA CODE 2013.

Peraturan Menteri Negara BUMN No.Per-05/MBU/2007.

\section{Putusan Peradilan}

Putusan Mahkamah Konstitusi Nomor 53/PUU-VI/2008 


\section{Internet}

Daniri, Mas Achmad, 2008, Standardisasi Tanggung Jawab Sosial perusahaan", diakses terakhir 21 maret 2015 di http://kadin-indonesia.or.id/ enm/images/dokumen/KADIN-167-3770-15042009.pdf

Mandatory Corporate Social Responsibility: Is the Government Shifting its Failure to Corporate India?https://socialissuesindia.files.wordpress.com/2012/12/ mandatorycsrinindia.pdf, diakses terakhir 4 agustus 2016.

Taufik, Ahmad, Hak Asasi Manusia dan Tanggung Jawab Sosial Perusahaan, di http:/ / bandungfreeschool.wordpress.com/2008/11/29/hak-asasimanusia-dan-tanggung-jawab-sosial-perusahaan/, diakses terakhir 13 Maret 2016. 